\title{
An assessment of water withdrawal effect on water quality of the downstream river at the Mamloo Dam site using the QUAL2E model
}

\author{
A. Torabian ${ }^{1}$, S. H. Hashemi ${ }^{2}$ \& A. A. Ghadimkhani ${ }^{2}$ \\ ${ }^{I}$ Department of Civil-Environmental Engineering, \\ University of Tehran, Iran \\ ${ }^{2}$ University of Tehran, Iran
}

\begin{abstract}
Mamloo Dam is under construction downstream of the Jajrood River to supply Varamin plain's irrigation water, flood control and produce energy.

The river water quality as DO, BOD and temperature and its self-purification capacity was studied to define the minimum safe water flow downstream of the dam.

The results show that the water quality will not change considerable upstream of the Parchin complex. However, after the complex outfall, the river water quality changes severely; even the effluent is treated up to National standard levels.

The main reasons for the changes in river water quality are Parchin high water withdrawal as well as the high ratio of its effluent to the river flow. The dam construction will raise this effect significantly.

The results show that national effluent standards, which are based on pollution concentration without considering waste loads and receiving environmental conditions in some cases cannot be satisfied and promulgation and enforcement of effluent standards are necessary.
\end{abstract}

Keywords: Mamloo Dam, Jajrood River, BOD5, water quality, QUAL2E model.

\section{Introduction}

Tehran Regional Water Board was studying a dam construction downstream Latian dam on Jajrood River. The primary objectives of the Mamloo dam are the storage and regulation of the Latian dam overload to supply Varamin plain's 
irrigation water and the other objectives are flood control and energy production [2].

The Mamloo dam is under construction $12.5 \mathrm{~km}$ downstream of the Jajrood and Damavand River junction with the longitude of $51^{\circ} 30^{\prime} 30^{\prime \prime}$ and latitude of $35^{\circ} 33^{\prime} 7^{\prime \prime}$. The site is located in the Darvazeh area, which is part of the Jajrood protected area, beside the Karaj and Sorkhehesar national parks. Mamloo dam construction was started in 2003 and it is expected to be completed by 2006 [2].

The study area is located in Darvazeh basin, which is including sub-basins of Jajrood, Damavand and a few other rivers. The Jajrood river is located to the Northwest and the Damavand River is located to the Northeast of Tehran city. The rivers flow to the South, and joint each other in Yourshadbala station and finally discharge to the Varamin plain [2].

The area of dam basin is $1750 \mathrm{~km}^{2}$. The dam has a height of $87 \mathrm{~m}, 772 \mathrm{~m}$ length in crest and 229 million- $\mathrm{m}^{3}$ capacity [2].

Annual discharge of the river is 289 million- $\mathrm{m}^{3}$ at the Damavand and Jajrood junction station. Maximum flood potential is estimated as $3000 \mathrm{~m}^{3} / \mathrm{s}$, and flood volume of 163 million- $\mathrm{m}^{3}$. The Main pollution sources of the Jajrood and Damavand Rivers are domestic wastewater of Damavand, Roodhen, Fasham, and Lavasan cities, Parchin Complex (include about 1500 residential units), and leachate of Abali closed landfill and fish farms, which discharge their raw wastewater without any treatment. More than 173000 persons lived in the study area in year 1996, which doubled in 20 last years due to rapid development of Boomhen, Pardis and Roodhen cities, foundation of the new cities of Pardis and Valiasr, and extension of Azad Islamic University of Roodhen [2].

\section{Materials and methods}

\subsection{QUAL2E model}

QUAL2E, which is supported by the USEPA, is a one-dimensional stream water quality model. The model can simulate 15 water quality variables include Nitrogen and Phosphorous cycles, algae, DO, BOD5, temperature, coli forms, one non-conservative and three conservative materials [1].

\subsection{Study Area}

The study area covers the Jajrood River, downstream Latian dam (station 4), Damavand River, downstream Damavand (station 1) and downstream Parchin Complex before the river enters to Varamin plain (station 8).

Eight stations were selected to evaluate the river water quality (Figure 1). Eight sampling periods were considered in low and high flow months from the autumn of 1997 to autumn 1998. The composite samples were taken in 8 hours periods. The pollution sources recognized by field survey and adequate samples were taken to determine their quality. The samples immediately was sent to laboratory and analyzed according to Standard Methods for Water and Wastewater Examination procedures [5]. 
QUAL2E was used to calculate the river self-purification capacity and minimum flow of the river, downstream of the dam, which can preserve the water quality for downstream uses. The simulated water quality variables were temperature, $\mathrm{DO}$, and $\mathrm{BOD}$.

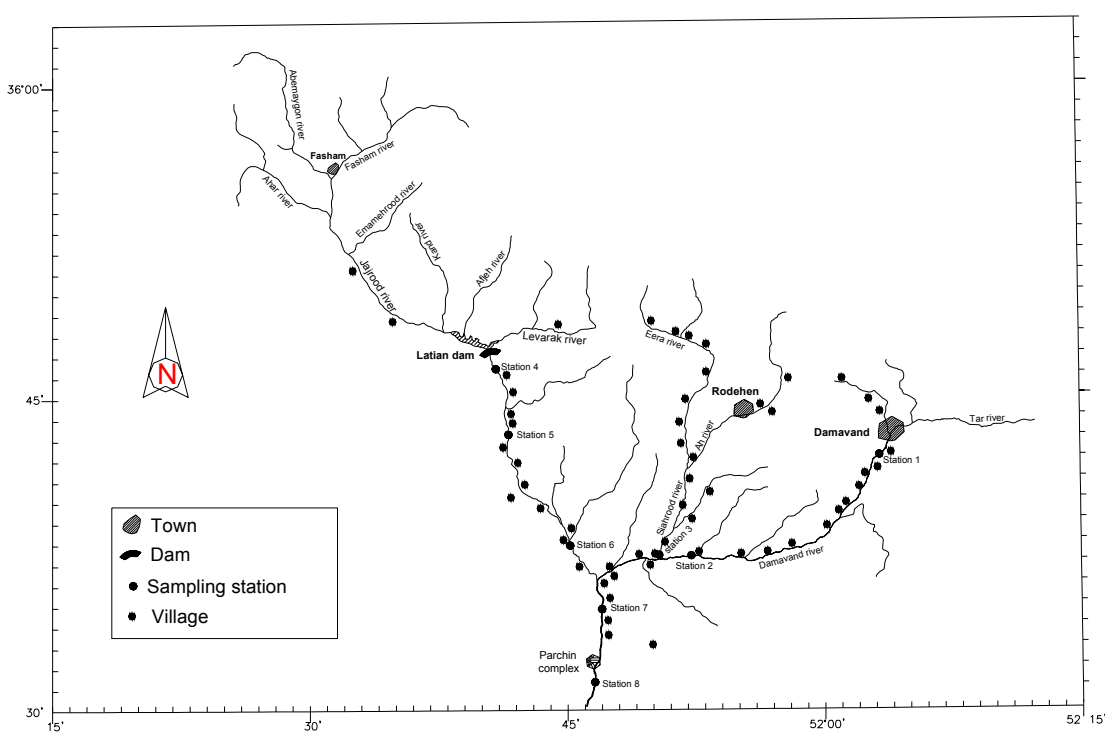

Figure 1: Mamloo river basin and location of sampling stations.

The main branch of the river has $43 \mathrm{~km}$ and the side branch has $21 \mathrm{~km}$ length. The main branch divided to eight reaches and side branch divided to six reaches with the same hydraulic conditions and segment length of $0.5 \mathrm{~km}$. The river cross section is considered trapezoidal. Due to the lack of adequate site-specific data, model default data as well as guideline values introduced in the references used as constants and coefficients [2].

Considering the hydraulic conditions of the river O'Conner and Dobbins equations were estimated to calculate re-aeration. The selection was done based on Covar (1978) method that suggests the proper equation based on the depth and velocity of water in the river [1].

There is one point source in the main branch and seven in the side branch (Table 1). The Mamloo dam is located in $12.5 \mathrm{~km}$ downstream of the main branch and $37.5 \mathrm{~km}$ of the side branch. Incremental flows were determined through calibration. Due to slightly polluted water in the river, the dam reaeration coefficients were estimated as 1.6 and 1.4 based on the model guideline [1]. 
Table 1: Point sources specification.

\begin{tabular}{|l|c|c|c|c|}
\hline point source & $\begin{array}{c}\text { Flow } \\
\left(\mathrm{m}^{3} / \mathrm{s}\right)\end{array}$ & $\begin{array}{c}\text { Temperature } \\
(\mathrm{C})\end{array}$ & $\begin{array}{c}\text { DO } \\
(\mathrm{mg} / \mathrm{l})\end{array}$ & BODu (mg/l) \\
\hline Mahisara & 84456 & 18.3 & 7.7 & 6 \\
\hline Targhian village & 5 & 18 & 2 & 276 \\
\hline Shenjeria village & 12.8 & 18 & 2 & 293 \\
\hline Takht e Chenr village & 7 & 18 & 2 & 284 \\
\hline Khajir village & 31.8 & 18 & 2 & 304 \\
\hline Takht-e-Parchin village & 9.2 & 18 & 2 & 288 \\
\hline Parchin Complex & 198720 & 18 & 4 & 23 \\
\hline
\end{tabular}

\section{Results and discussion}

QUAL2E model was used to determine the minimum flow of the river downstream of the dam to test if the water quality and quantity were acceptable for planning uses. The results show that different pollution sources have no considerable effect on water quality of the river upstream of Parchin Complex due to adequate self-purification potential of the river whereas downstream of the Parchin Complex the quality changes significantly. The main reasons are the high water withdrawal of the Parchin complex as well as the high ratio of its effluent to the river flow (Table 2). High water withdrawal for planned uses will result in a lower dilution ratio downstream Parchin outfall than normal conditions (Table 3). For example, the results show that while the river BOD5 is $10.3 \mathrm{mg} / \mathrm{l}$ after the Parchin outfall in zero withdrawal, it will reach $11 \mathrm{mg} / \mathrm{l}$ and $11.3 \mathrm{mg} / \mathrm{l}$ after $1 \mathrm{~m}^{3} / \mathrm{s}$ and $3 \mathrm{~m}^{3} / \mathrm{s}$ withdrawal in June, respectively $[2,6]$.

Table 2: $\quad$ The river water quality upstream and downstream Parchin outfallform January 1997 to September 1998.

\begin{tabular}{|l|l|c|c|c|c|c|c|c|}
\hline \multirow{2}{*}{ Month } & \multicolumn{2}{|l|}{ Flow $\left(\mathrm{m}^{3} / \mathrm{s}\right)$} & \multicolumn{2}{l|}{ Temperature $(\mathrm{C})$} & \multicolumn{2}{l|}{ DO $(\mathrm{mg} / \mathrm{l})$} & \multicolumn{2}{c|}{ BOD $_{5}(\mathrm{mg} / \mathrm{l})$} \\
\cline { 2 - 10 } & Before & After & Before & After & Before & After & Before & After \\
\hline January & 3.70 & 5.99 & 7.0 & 11.1 & 11.2 & 8.5 & 2.8 & 10.3 \\
\hline February & 3.39 & 5.51 & 10.5 & 13.5 & 10.3 & 7.8 & 5.0 & 12.0 \\
\hline March & 8.69 & 11.04 & 14.6 & 15.3 & 9.4 & 8.3 & 6.3 & 9.6 \\
\hline April & 6.40 & 8.56 & 20.5 & 19.8 & 8.4 & 7.2 & 1.8 & 7.2 \\
\hline May & 5.70 & 7.89 & 20.5 & 19.8 & 8.2 & 7.0 & 5.4 & 10.3 \\
\hline June & 5.60 & 7.86 & 17.6 & 17.7 & 8.8 & 7.4 & 2.5 & 8.2 \\
\hline July & 6.31 & 8.45 & 17.7 & 17.8 & 8.8 & 7.6 & 1.9 & 7.3 \\
\hline
\end{tabular}




\section{Conclusions}

The results show that Mamloo dam construction has no significant effect on the river water quality as DO and BOD upstream of Parchin outfall in spite of existing different pollution sources. However, after the Parchin outfall the river water quality alters significantly (Figure 2). The change intensity is proportional to the river flow upstream of the Parchin outfall.

Tables 4 and 5 show a comparison between the river water quality in different stations and common water resources quality criteria of Iran DOE as well as environmental quality standards for water pollutants of Japan. It shows that the river water quality is almost above the desirable level of BOD5 along the length of the river throughout the year and construction of the dam will raise the problem downstream dam (Figure 2) $[3,7]$.

Table 3: $\quad$ The river water quality upstream and downstream Parchin outfall for different water.

\begin{tabular}{|c|c|c|c|c|c|c|c|c|c|}
\hline \multirow[b]{3}{*}{ Month } & \multicolumn{9}{|c|}{$1 \mathrm{~m}^{3} / \mathrm{s}$ water withdrawal } \\
\hline & \multicolumn{4}{|c|}{ Upstream Parchin outfall } & \multicolumn{5}{|c|}{ Downstream Parchin outfall } \\
\hline & 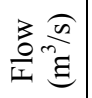 & 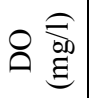 & 仓ิ & $\underset{\Theta}{\dot{\Xi}}$ & $\frac{3}{a^{2}} \stackrel{(n}{\Xi}$ & 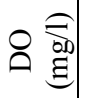 & & 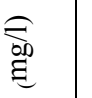 & 悹 \\
\hline January & 2.69 & 11.3 & 2.8 & 7.0 & 4.99 & 8.0 & & 11.9 & 12.0 \\
\hline February & 2.39 & 10.3 & 5.0 & 10.5 & 4.51 & 7.3 & & 13.6 & 14.1 \\
\hline March & 7.69 & 9.4 & 6.3 & 14.6 & 10.04 & 8.2 & & 9.9 & 15.4 \\
\hline April & 5.40 & 8.4 & 1.8 & 20.5 & 7.56 & 7.1 & & 7.9 & 19.8 \\
\hline May & 4.70 & 8.2 & 5.5 & 20.5 & 6.89 & 6.8 & & 11.0 & 19.7 \\
\hline June & 4.60 & 8.8 & 1.9 & 17.6 & 6.89 & 6.1 & & 9.5 & 17.8 \\
\hline July & 5.31 & 8.8 & 1.9 & 17.7 & 7.45 & 7.4 & & 8.0 & 17.8 \\
\hline \multirow[b]{3}{*}{ Month } & \multicolumn{9}{|c|}{$3 \mathrm{~m}^{3} / \mathrm{s}$ water withdrawal } \\
\hline & \multicolumn{4}{|c|}{ Upstream Parchin outfall } & \multicolumn{5}{|c|}{ Downstream Parchin outfall } \\
\hline & 总䍃 & 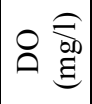 & 仓ิ & 官 & 疍䍃 & $\circ$ & $\underset{\sigma 0}{\sigma}$ & 仓ิ & 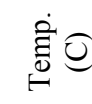 \\
\hline January & 0.69 & $\begin{array}{r}11 . \\
3\end{array}$ & 2.7 & 7.1 & 2.99 & & 5.7 & 18.2 & 15.4 \\
\hline February & 0.39 & $\begin{array}{r}10 . \\
4\end{array}$ & 4.8 & 10.5 & 2.51 & & 4.9 & 20.3 & 16.9 \\
\hline March & 5.69 & 9.4 & 6.3 & 14.7 & 8.04 & & 7.9 & 10.8 & 15.7 \\
\hline April & 3.40 & 8.4 & 1.8 & 20.5 & 5.56 & & 6.6 & 10.1 & 19.5 \\
\hline May & 2.70 & 8.2 & 5.5 & 20.6 & 4.89 & & 6.3 & 13.3 & 19.4 \\
\hline June & 2.60 & 8.8 & 2.5 & 17.7 & 4.86 & & 6.6 & 11.9 & 17.8 \\
\hline July & 3.31 & 8.8 & 1.9 & 17.7 & 5.45 & & 6.9 & 10.3 & 17.8 \\
\hline
\end{tabular}


162 Water Pollution VIII: Modelling, Monitoring and Management

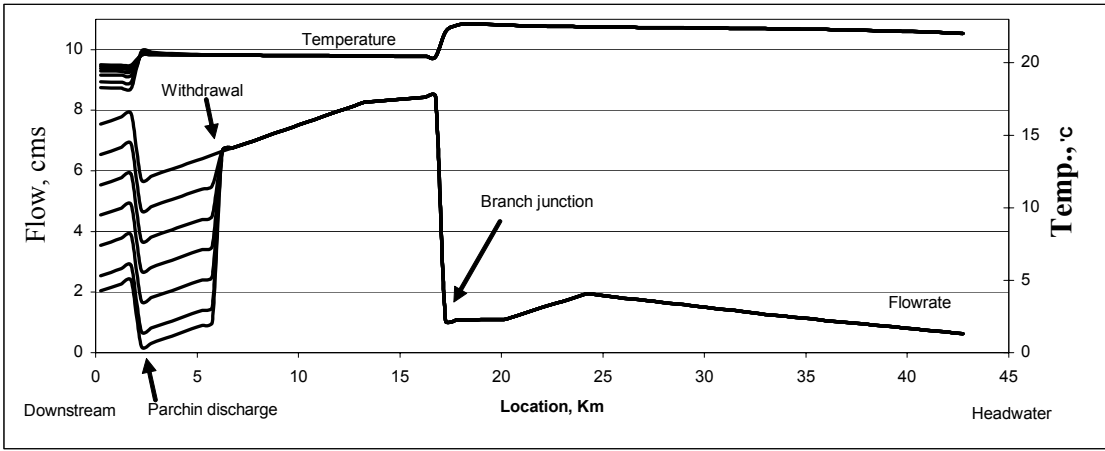

(a)

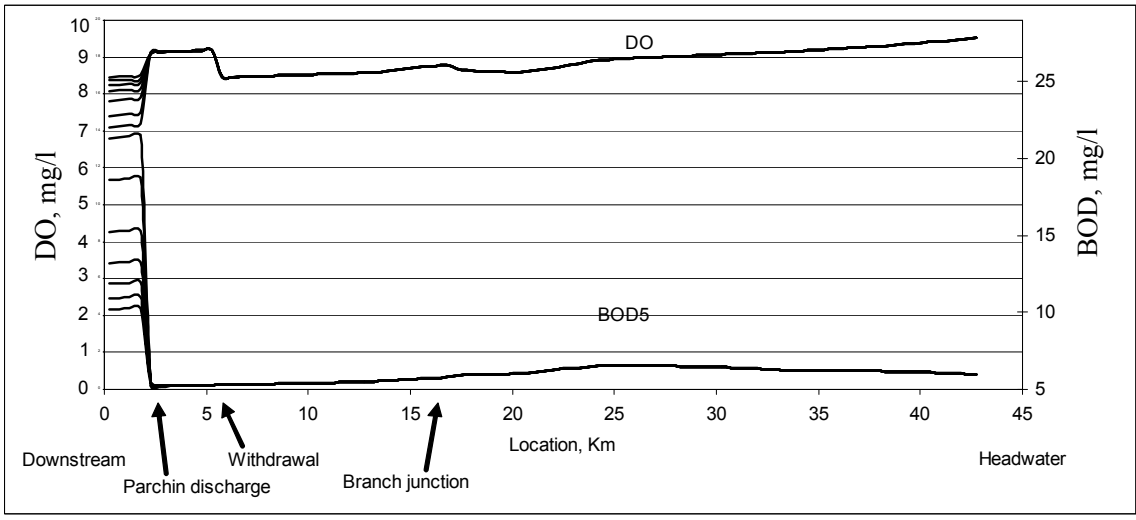

(b)

Figure 2: $\quad$ Changes of (a) Flow, Temperature (b) BOD, DO at main branch in June versus flow withdrawal of $1,2,3,4,5$ and 5.5 cubic meter per second.

Table 4: $\quad$ Common water resources quality of Iran DOE.

\begin{tabular}{|c|c|c|c|c|}
\hline $\begin{array}{c}\text { Total Coliforms } \\
\text { MPN/ } 100 \mathrm{ml}\end{array}$ & PH & $\begin{array}{c}\text { TDS } \\
\mathrm{mg} / \mathrm{l}\end{array}$ & $\begin{array}{c}\mathrm{BOD}_{5} \\
\mathrm{mg} / 1\end{array}$ & $\begin{array}{c}\mathrm{DO} \\
\mathrm{mg} / 1\end{array}$ \\
\hline 400 & $6.5-9$ & 750 & 5 & 5 \\
\hline
\end{tabular}


Table 5: Environmental quality standards for water pollutants of Japanrivers.

\begin{tabular}{|c|c|c|c|c|c|c|}
\hline \multirow{2}{*}{ Class } & \multirow{2}{*}{\begin{tabular}{|r|} 
Item \\
Water use \\
\end{tabular}} & \multicolumn{5}{|c|}{ Standard value } \\
\hline & & $\mathrm{pH}$ & BOD & SS & DO & Total coli forms \\
\hline AA & $\begin{array}{l}\text { Water supply class } \\
1, \\
\text { conservation } \\
\text { natural } \\
\text { environment } \\
\text { uses listed in } \\
\text { A-E }\end{array}$ & $6.5-8.5$ & $1 \mathrm{mg} / 1$ or less & $\mid \begin{array}{l}25 \mathrm{mg} / \mathrm{l} \text { or } \\
\text { less }\end{array}$ & $\begin{array}{l}7.5 \\
\mathrm{mg} / 1 \\
\text { or } \\
\text { more }\end{array}$ & $\begin{array}{l}50 \mathrm{MPN} / 100 \mathrm{ml} \\
\text { or less }\end{array}$ \\
\hline A & $\begin{array}{l}\text { Water supply class } \\
2, \\
\text { fishery class } 1, \\
\text { bathing and uses } \\
\text { listed in B-E }\end{array}$ & $6.5-8.5$ & $2 \mathrm{mg} / \mathrm{l}$ or less & $\begin{array}{l}25 \mathrm{mg} / \mathrm{l} \text { or } \\
\text { less }\end{array}$ & $\begin{array}{l}7.5 \\
\mathrm{mg} / 1 \\
\text { or } \\
\text { more }\end{array}$ & $\begin{array}{l}1000 \mathrm{MPN} / 100 \mathrm{ml} \\
\text { or less }\end{array}$ \\
\hline B & $\begin{array}{l}\text { Water supply class } \\
3, \\
\text { fishery class } 2, \\
\text { and uses listed in } \\
\text { C-E }\end{array}$ & $6.5-8.5$ & $3 \mathrm{mg} / \mathrm{l}$ or less & $\begin{array}{l}25 \mathrm{mg} / \mathrm{l} \text { or } \\
\text { less }\end{array}$ & $\begin{array}{l}5 \\
\mathrm{mg} / 1 \\
\text { or } \\
\text { more }\end{array}$ & $\begin{array}{l}5000 \mathrm{MPN} / 100 \mathrm{ml} \\
\text { or less }\end{array}$ \\
\hline $\mathrm{C}$ & 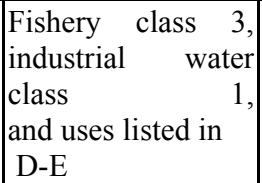 & $6.5-8.5$ & $5 \mathrm{mg} / \mathrm{l}$ or less & $\left\{\begin{array}{l}50 \mathrm{mg} / \mathrm{l} \text { or } \\
\text { less }\end{array}\right.$ & $\begin{array}{l}5 \\
\mathrm{mg} / 1 \\
\text { or } \\
\text { more }\end{array}$ & - \\
\hline $\mathrm{D}$ & $\begin{array}{|lr|}\text { Industrial } & \text { water } \\
\text { class } & 2, \\
\text { agricultural } & \text { water } \\
\text { and uses listed in E }\end{array}$ & $6.0-8.5$ & $8 \mathrm{mg} / \mathrm{l}$ or less & $\begin{array}{l}100 \mathrm{mg} / \mathrm{l} \\
\text { or less }\end{array}$ & $\begin{array}{l}2 \\
\mathrm{mg} / 1 \\
\text { or } \\
\text { more }\end{array}$ & - \\
\hline $\mathrm{E}$ & $\left|\begin{array}{lr}\text { Industrial } & \text { water } \\
\text { class } & 3 \\
\text { and } & \text { conservation } \\
\text { of environment }\end{array}\right|$ & $6.0-8.5$ & $\begin{array}{l}10 \mathrm{mg} / \mathrm{l} \text { or } \\
\text { less }\end{array}$ & \begin{tabular}{|l|} 
Floating \\
Matter \\
such as \\
garbage \\
should not \\
be \\
observed
\end{tabular} & $\begin{array}{l}2 \\
\mathrm{mg} / 1 \\
\text { or } \\
\text { more }\end{array}$ & - \\
\hline
\end{tabular}

(BOD: Biochemical Oxygen Demand, SS: Suspended Solids, DO: Dissolved Oxygen)

Notes:

1. The standard value is based on the daily average value. The same applies to the standard values of lakes and coastal waters.

2. At intake for agriculture, $\mathrm{pH}$ shall be between 6.0 and 7.5 and $\mathrm{DO}$ shall be more than $5 \mathrm{mg} / \mathrm{l}$. The same applies to the standard values of lakes. 


\section{Acknowledgements}

The authors would like to thank the research deputy of University of Tehran for supporting this study financially and Lar consulting engineers for the authorization to use their data.

\section{References}

[1] Brown, L. C. and Barnwell T. O. 1987. The Enhanced Stream Water Quality Models QIAL2E and QUAL2E-UNCAS: Documentation and User Manual.EPA/600/3-87/007. U. S. EPA. Athens, GA, USA.

[2] Environmental pollution studies. Environmental effect project of Mamloo storage dam. 1999. Lar Consulting Engineers.

[3] Environmental Quality Standards for Water Pollution, Standards Related to the Conservation of the Living Environment. 1993. Environment Agency, Government of Japan.

[4] G. L. Bowie et al. 1985. Kinetics, constants and rates formulation, Surface Water Quality Modeling; USEPA.

[5] Standard Methods for the Examination of Water and Wastewater. 1995. APHA, AWWA, WEF.

[6] Shanahan, P. et al., 2000. River water quality modelling: II. Problems of the art. IAWQ.

[7] Water quality studies of water sources guideline. 2001. Department of Environment of Iran. 